\title{
The Right to Self-Government After Bush v. Gore
}

\author{
Paul D. Carrington and H. Jefferson Powell
}

\begin{abstract}
Bush v. Gore was decided a year ago. As expected, it evoked a flood of journalistic and academic commentary. The present authors write to express dissatisfaction with the resulting literature. They find it in general to be dominated by the usual political discourse conducted from opposite ends of the usual political spectrum, with both ends sharing an assumption that the Supreme Court was animated in its decision by the usual political motives that it has become conventional to see in the actions of that institution. Left almost completely out of view have been the more personal selfish motives of the Justices that seem to the present authors to be obvious, unusual, and paramount. Those motives and the reluctance of others to comment on them are here taken to suggest that neither the Court nor its supporters or critics are seriously concerned, as these authors are, with the continuing decline of the right to self-government that is dramatically marked by yet another decision by Justices who demean the authority of elected officials.
\end{abstract}

\section{Form of Publication}

The authors have chosen this form of publication for two reasons. First, they are mindful that they are late in entering a discussion and that those aspects of the topic seeming to them to be of the greatest importance have been largely neglected in that discussion. By publishing electronically, their views can be presented a year earlier than they could be presented in conventional print media. Second, the authors hope to evoke comments from academic colleagues, lawyers and judges, and others interested in reflecting on the Court's disposition. Accordingly, anyone patient enough to read this brief paper and react to it is assured that their comments will be equally available to subsequent readers. This also permits us, if the occasion arises, publicly to acknowledge the force of new information or arguments that may be advanced by our readers. It is our hope that this format, or enhancements of it, will prove to be useful to other authors of other papers who seek to engage in public debate without the delays attending traditional forms of publishing. Readers who wish to participate in the discussion may visit http://www.law.duke.edu/pub/selfgov/.

\section{No Copyright}

This paper is dedicated to the public domain. If readers find it useful to repeat any part of it, it would be a professional courtesy to cite the present authors, but no property right is claimed. 
With reluctance, we add our voices to the academic clamor over Bush v. Gore. ${ }^{1}$ We do so because we are distressed that so much of that clamor has been predictable on the basis of the political alignment of the authors, whether they be among those dismissed by Chief Judge Richard Posner as "liberals" who want a Court to do their ideological bidding $^{2}$ or whether like the judge himself they seem to be ideological allies of the majority of the Court defending the decision with reckless disregard for the transparency of their arguments.

Critics and defenders of the Court alike have supposed that the Justices were motivated by conventional political instincts, selecting a President whose political ideology was closer to their own and repaying political debts to those who had conferred so much honor and power on them by appointing them to the Court. We do not share that suspicion. We have confidence that all nine members of the Court when deciding cases are able to lay aside their ideological preferences among candidates for public office and that none would repay their private debts from public stock.

1 There were really three cases that are the object of attention: Bush v. Palm Beach County Canvassing Bd., 531 U.S. 70 (Dec. 4, 2000) (vacating Florida Supreme Court's initial decision and remanding for clarification); Bush v. Gore, 531 U.S. 1046 (Dec. 9, 2000) (staying the recount ordered by the Florida court); Bush v. Gore, 531 U.S. 98 (Dec. 12, 2000) (reversing the Florida court's recount decision).

2 Breaking the Deadlock: THE 2000 Election, The Constitution AND THE COURT 150-189 (2001).
We perceive, however, that the professional integrity of the Court was subverted by a form of self-interest much more powerful than mere ideology, one seldom noted in the literature and one that all the Justices should have recognized as disqualifying them from sitting on such a case. That interest is their own personal status and power.

Each Justice has a direct personal interest in the identity of the person who will appoint his or her colleagues. Particularly for members of a Court as evenly and constantly divided as the Rehnquist Court, a single unwelcome appointment would demote the five in the majority from the power to decide the Court's important cases to the impotence of dissent. Nothing save death or serious illness could be a more distressing prospect to a Justice sitting in the majority of such a Court. In like manner, a single welcome appointment would promote the four in the minority from a position of perpetual impotence to a position of gratifying power. Nothing, not even a large cash bequest, could be a more welcome prospect to a Justice sitting as a member of a frustrated minority. If there were ever a case in which the Court should have refused to exercise jurisdiction, Bush v. Gore would seem to us to be it. That they did decide it should have occasioned their denunciation on all sides, but there have been only a few polite murmers about this aspect of the case.

That all the Justices were disqualified from sitting on the case is, however, only one element of our protest. The additional point we wish to make is that not only the self-aggrandizing decision in Bush v. Gore, but much of the commentary by both friends and foes expresses or at least reflects a chronic and growing disrespect for the institutions of 
self-government. The ends of the political spectrum appear to us to be united in their unseemly enthusiasm for what has become known as the Court's counter-majoritarianism.

We would like to be reassured that members of the Court and of its academic audience can recall the prose of Jefferson in the Declaration. ${ }^{3}$ Or of the Framers in the Preamble. ${ }^{4}$ Or of Lincoln at Gettysburg. ${ }^{5}$ Or that any have read Article 21 of the Universal Declaration of Human Rights and considered its possible application to citizens of the United States. ${ }^{6}$ It seems to us that the Court has for some time lost touch (if it was ever really in touch) with its responsibility for the nurture and protection of representative government and has acquired the habit of deciding just about any interesting question that comes its way with little or no regard for the preferences of those who were elected to decide them. It thus appears to us to present inadequate respect for the other branches of the federal government, or for the institutions of state and local government. Bush v. Gore should be

3 .. That to secure these rights, Governments are instituted among Men, deriving their power from the consent of the governed.

4 We the People of the United States ... do ordain and establish this Constitution.

5 ... We resolve ... that government of the people, by the people, and for the people shall not perish from the earth.

6 . The will of the people shall be the basis of the authority of government; this will shall be expressed in periodic and genuine elections which shall be by universal and equal suffrage and shall be held by secret vote or by equivalent free voting procedures. taken, as it has not been, to dispel the illusion that the judiciary is "the least dangerous branch."

Believing as we do in the wisdom of the rhetoric noted and in the right of citizens to govern through elected representatives, we hold that the ubiquitous and most important duty of the Supreme Court of the United States is to mind its own business and respect the roles of other institutions of government. Its complete failure to perform that duty in Bush v. Gore is the cause of our disappointment. It also disappoints but does not surprise us that Judge Posner, the author of a book about the importance of Overcoming Law in order to reach gratifying results, should see nothing terribly wrong about the Court's disregard of controlling legal texts and traditions to spare the nation a period of uncertainty about the outcome of the election. With regret, we take his point that many of the Court's critics have long espoused an expanded political role for the Court to which the decision in Bush v. Gore can be seen as a suitable response. We cannot deny that the admirers of Justice William Brennan on and off the Court have indeed "overcome law" in the belief that the Justices could and should make up for any shortfall in the humanitarian impulses of other "majoritarian" branches and elements of American government, a competence that we and some others deny. By "overcoming law" with impugnity, they have contributed mightily to the sad state of representative government in America.

Chief Justice William Rehnquist in the days when he was a fulminating dissenter to the Brennan Court cautioned his brethren against the ubiquitous temptation to exceed their authority by quoting John Stuart Mill: 
The disposition of mankind, whether as rulers or fellow citizens, to impose their own opinions and inclinations as a rule of conduct for others, is so energetically supported by some of the best and some of the worst feelings incident to human nature, that is hardly ever kept under constraint by anything but want of power. ${ }^{7}$

Alas that the Chief Justice was unable to restrain himself in Bush v. Gore. No doubt he rationalized his decision as a manifestation of his better "feelings," but that should not conceal the nature of his act from others who understand political power and its malign effects on those who possess it, whatever their political persuasion.

Our keenest disappointment, however, is with the performance of Justice Antonin Scalia, who has long and ardently presented himself as an advocate of the self-restraint required by judges participating in a republican form of government. We therefore first review his utterances of principles with many of which we are in agreement. We will then measure his performance in Bush v. Gore against the standards he has proclaimed for himself and others, taking separately his votes for the per curiam opinion of the Court, the concurrence in which he joined, and the order staying further counting of the votes.

\section{JUSTICE SCALIA ON THE RIGHT TO SELF-GOVERNMENT}

"I take the need for theoretical legitimacy seriously," Scalia wrote in a 1989 article, and he has repeatedly (and correctly in our view) linked the issue of judicial legitimacy with his understanding of "the nature and purpose of a Constitution in a democratic system." "The courts of the United States derive all their power from an instrument (the United States Constitution) which begins: 'We, the people of the United States ...' It is quite impossible for the courts, creatures and agents of the people of the United States, to impose upon those people of the United States norms that those people themselves (through their democratic institutions) have not accepted." 9 The fundamental principle of American constitutionalism according to Justice Scalia is "the eminently democratic principle that --except where constitutional imperatives intervene- the majority rules."10

For Justice Scalia the overriding desideratum of a theory of constitutional interpretation was said to be to enable courts to carry out their limited function of safeguarding justiciable constitutional imperatives while ensuring that judges do not trespass on the broad grounds of legitimate democratic decision-making by substituting their own policy preferences

8 Antonin Scalia, Originalism: The Lesser Evil, 57 U. CIN. L. REV. 849, 862 (1989).

9 Antonin Scalia, Commentary, 40 St. LouIs U. L.J. 1119, 1119 (1996).

10 California Democratic Party v. Jones, 530 U.S. 567, 584 (2000) (Scalia, J., for the Court). 
for those of political actors. This is no easy task, Scalia admits: "Now the main danger in judicial interpretation of the Constitution--or, for that matter, in judicial interpretation of any law--is that the judges will mistake their own predilections for the law. Avoiding this error is the hardest part of being a conscientious judge; perhaps no conscientious judge ever succeeds entirely." $"$ It is fair to assume, we believe, that Scalia's frequent statements of interpretive principle reflect his belief that both he and his colleagues are at risk of committing this anti-democratic error and are less likely to succumb to temptation the more clearly they keep before them the proper approach to interpretation.

Justice Scalia has identified two general principles of constitutional interpretation that, taken together, he believes capable of guiding judicial review in a manner respectful of democratic prerogatives. The first of these is adherence to the plain meaning of a controlling text. ${ }^{12}$

But of course meaning is often less than plain. Where the text is cast in terms of great generality, this invites even a judge wishing to be conscientious about respecting democracy to read into the provision "notions of fairness or textual fidelity" "13 that were not in fact endorsed by the democratic processes conferring legitimacy on the text. The Due Process

11 Antonin Scalia, Originalism: The Lesser Evil, 57 U. CIN. L. REV. at 863.

${ }^{12}$ Id.

13 Antonin Scalia, Assorted Canards of Contemporary Legal Analysis, 40 CASE W. RES. L. REV. 581, 589 (1990). and Equal Protection Clauses are obvious examples of such provisions.

When enforcing those provisions, Justice Scalia asserts that the Court cannot identify and protect against the political process an individual right that "is not to be found in the longstanding traditions of our society, [or] logically deduced from the text of the Constitution." ${ }^{14}$ The Court must then, he tells us, give determinative weight in such cases to what he often calls tradition. "The distinction between what is needed to support novel procedures and what is needed to sustain traditional ones is fundamental;" a practice that "is one of the continuing traditions of our legal system ... define[s]" what due process and equal protection meant and, thus, mean. ${ }^{15}$ Challenges to traditional practices are to be answered "on the basis of the "timedated' meaning of equal protection in 1868;" adherence to practices that were accepted at the time the amendment was adopted "does not violate the Fourteenth Amendment, because that is not what 'equal protection of the laws' ever meant."16 The "time-dated"" historical

\section{4}

Ohio v. Akron Center for Reproductive Health, 497 U.S. 502, 520 (1990) (Scalia, J., concurring).

15 Burnham v. Superior Court, 495 U.S. 604, 619 (1990) (plurality opinion of SCALIA, J.). Burnham was a due process case. Justice Scalia has endorsed the same approach to equal protection issues. In addition to the quotation in the text, see, e.g., J.E.B. v. Alabama ex rel. T.B., 511 U.S. 127, 156-163 (1994) (Scalia, J., dissenting); United States v. Virginia, 518 U.S. 515, 568-69 (1996) (Scalia, J., dissenting)

16 Scalia, Response, in ANTONIN SCALIA ET AL., A MATTER OF INTERPRETATION: FEDERAL COURTS AND THE LAW 148-49 (1997). Justice Scalia's remarks were an amplification of his earlier assertion 
meaning of the Due Process and Equal Protection clauses thus takes priority over the meaning that a Justice might ascribe to the text in the abstract on the basis of his or her "notions of fairness or textual fidelity."

The Scalia votes in Bush v. Gore were dramatic departures from these principles. The plain meaning of the constitutional text of Article II and the "time-dated" meaning of the Equal Protection Clause both pointed, beyond question it seemed to us, in the direction opposite to that taken by him. We would especially welcome enlightenment from

that what constitutes a denial of equal protection on the basis of sex is fixed by the meaning of the fourteenth amendment "when it was adopted." See Scalia, Common-Law Courts in a Civil-Law System, in id. at 47. (Scalia was responding to Professor Ronald Dworkin's criticism that Scalia's "time-dated" interpretation of the equal protection clause "reads into that language limitations that the language ... cannot bear." Dworkin, Comment, in id. at 126.) Scalia responded that Dworkin "quite entirely mistakes my position. ... Denial of equal protection on [various grounds including sex] is prohibited but that still leaves open the question of what constitutes a denial of equal protection."

Is it a denial of equal protection on the basis of sex to have segregated toilets in public buildings, or to exclude women from combat? I have no idea how Professor Dworkin goes about answering such a question. I answer it on the basis of the "time-dated" meaning of equal protection in 1868 . Unisex toilets and women assault troops may be ideas whose time has come, and the people are certainly free to require them by legislation; but refusing to do so does not violate the Fourteenth Amendment, because that is not what "equal protection of the laws" ever meant. readers who think they can reconcile his self-serving votes with his previous rhetoric regarding the proper role of the Court as one feature of a democratic government.

\section{The Per CURIAM OPINION OF THE COURT: "TIME-DATED" MEANING}

We consider first his vote in support of the per curiam opinion of the Court. Justice Scalia was one of seven Justices holding that the decision of the Florida Supreme Court calling for a hand recount of the undervote was a denial of Equal Protection of the Law because that court failed to specify detailed standards as to how that recount was to be conducted, thus leaving open the possibility that between two identical ballots one might be counted and the other not because those doing the recounting were applying different standards.

Unaccountably to us, none of the parties or amici in Bush v. Gore briefed the question of the historical understanding of ballot counting and Equal Protection in 1868, although Vice President Gore's lawyers did note, correctly, that the Florida court's general "intent of the voter" standard, which the state court drew from the Florida election code, ${ }^{17}$ was well within the mainstream of current and longstanding practice in many states. ${ }^{18}$ This failure of proof ought itself

17 "No vote shall be declared invalid or void if there is a clear indication of the intent of the voter as determined by the canvassing board." Fla. St. § 101.5614, cited in Gore v. Harris, 772 So. 2d at 1262.

18 See Brief for Respondent Albert Gore, Jr., Bush v. Gore, at 44-46. 
to have made it problematic at best for Justice Scalia to join an opinion resting on the Equal Protection argument. In other contexts involving broadly stated individual rights provisions he has made it clear that the burden of persuasion rests on the party seeking to read into the provision a specific limitation. "For if the Constitution does not affirmatively contain such a restriction, the matter ... is left to state constitutions or to the democratic process." ${ }^{19}$ State action - at

19 Harmelin v. Michigan, 501 U.S. 957, 976 n.6 (1991) (Scalia, J., for the Court). The specific context was a disagreement between the majority and Justice White in dissent whether the cruel and unusual punishment clause of the eighth amendment imposes a general requirement of proportionality between crime and punishment. White argued that the clause does, in part because he found no evidence of "an [original] intention to exclude [such a requirement] from the reach of the words that otherwise could reasonably be construed to include it." Id. at 1011 (White, J., dissenting). Justice Scalia replied that White's argument "[s]urely [was] an extraordinary method for determining what restrictions upon democratic self-government the Constitution contains."

It seems to us that our task is not merely to identify various meanings that the text "could reasonably" bear, and then impose the one that from a policy standpoint pleases us best. Rather, we are to strive as best we can to select from among the various "reasonable" possibilities the most plausible meaning. We do not bear the burden of "proving an affirmative decision against the proportionality component," ibid.; rather, Justice WHITE bears the burden of proving an affirmative decision in its favor. For if the Constitution does not affirmatively contain such a restriction, the matter of proportionality is left to state constitutions or to the democratic process. least state action that is not (in Justice Scalia's view) a per se violation of the Constitution $^{20}$ - supposedly enjoys for Scalia a genuine presumption of constitutionality, a presumption that he did not apply in Bush v. Gore.

Our disappointment in Justice Scalia's decision to join the per curiam opinion deepens when we turn from presumptions regarding traditional practice to substance. Even without the assistance of counsel, Scalia or his clerks could easily have discovered (as one of us

Id. at 976 n.6. See also City of Boerne v. Flores, 521 U.S. 507, 544 (1997) (Scalia, J., concurring) (meaning of free exercise clause); Cruzan by Cruzan v. Director, Missouri Dept. of Health, 497 U.S. 261, 300 (Scalia, J., concurring) (meaning of due process clause). We are aware of nothing written by Justice Scalia suggesting that he would endorse a different approach to the equal protection clause.

20 Justice Scalia's position on racebased affirmative action is presumably an example of a per se violation of the text of the equal protection clause, since his views are inconsistent with, among other matters, the apparent original understanding of the clause. Compare Adarand Constructors, Inc. v. Pena, 515 U.S. 200, 239 (1995) (Scalia, J., concurring in part and in the judgment) with Jed Rubenfeld, Affirmative Action, 107 YALE L.J. 427, 427 (1997) ("Congress in the 1860s repeatedly enacted statutes allocating special benefits to blacks on the express basis of race (and I am not referring to the well-known Freedmen's Bureau Acts, which did not rely on express racial classifications). Accordingly, to be true to their principles, two of the five Justices in the prevailing anti-affirmative action majority-- Justices Scalia and Thomas, whose commitment to original understandings and practices is also a matter of record--should drop their categorical opposition to race-based affirmative action measures."). 
did in a few hours in the library) that the practice of permitting after-the-fact evaluation of ballots on a highly general intent of the voter standard, a practice constitutionally indistinguishable from the standard set forth by the Florida court, was extremely widespread in the period leading up to 1868 , and indeed apparently unchallenged.

The earliest important case that Justice Scalia might have regarded as the foundation of a tradition was decided in New York in 1827, People ex rel. Yates $v$. Ferguson. ${ }^{21}$ The question in Ferguson was whether ballots identifying "H.F. Yates" as the candidate chosen should be counted as votes for a candidate named Henry F. Yates. In concluding that they could be so counted, the court noted that it was the practice of New York's state elections board to count abbreviated names as valid votes for a candidate, despite the existence of a statute requiring a lawful ballot to contain the candidate's name, when "the canvassers adjudge that the abbreviation represents the word, which word represents the name of the person voted for," and that this practice was justifiable only because "the abbreviation is evidence of the intent of the voter." A fortiori, the court concluded, a jury hearing a case involving ambiguous ballots was entitled to consult whatever "testimony, facts and circumstances," including the testimony of the voter himself, that would bear on the question for whom the voter intended to vote. ${ }^{22}$

The Ferguson court's holding that personal testimony was admissible to assist a jury in allocating an ambiguous

${ }^{21} 8$ Cow. 102 (N.Y. Supr. 1827).

${ }^{22}$ Id. at 107. ballot proved controversial. Several other states rejected that specific element of Ferguson. $^{23}$ In other respects, however, Ferguson was entirely typical of the decisions we have found from the four decades that separated Ferguson from the ratification of the Fourteenth Amendment. The reported cases from that period seem, almost invariably, to expect elections boards to apply a non-formalistic and quite general standard in deciding how to count ambiguous ballots. ${ }^{24}$ The case that seems to have gone the furthest in imposing a judicially crafted rule on the discretion of local elections officials was People ex rel. Williams v. Cicott, ${ }^{25}$ a case

23 See, e.g., People ex rel. AttorneyGeneral v. Tisdale, 1 Doug. 59, 63-64 (Mich. 1843); Attorney General ex rel. Carpenter v. Ely, 4 Wis. 438, 449 (1854). (The New York Court of Appeals itself later rejected the practice of permitting voters to testify as to their intentions. See People v. Saxton, 22 N.Y. 309, 311 (1860) ("The intention of the voter is to be inferred ... by a reasonable construction of his acts.")

${ }^{24}$ See, e.g., Ferguson, 8 Cow. at 106 (without "confin[ing] themselves to names written or printed at full length ... [t]he intent of the voter is to be ascertained by the canvassers"); Tisdale, 1 Doug. at 65 (canvassers "were to ascertain that intention from the votes," not permitting "a slight error" to "prevent the vote from being counted for the person for whom it was evidently intended"); Ely, 4 Wis. at 449 (voter's intent may be "explained by the surrounding circumstances, from facts of a general public nature, connected with the election, and the different candidates, which may aid you in coming to the right conclusion"); State ex rel. Spaulding v. Elwood, 12 Wis. 551 (1860); Day v. Kent, 1 Or. 123 (Oreg. Terr. 1854); People ex rel. Akin v. Matteson, 7 Peck 167 (Ill. 1855).

${ }^{25} 16$ Mich. 283 (1868). 
decided in Michigan in 1868, but even there the court acknowledged that canvassing officials should count imperfectly executed ballots where the ballot's appearance was "sufficient to show an intent to vote against the one [candidate] and for the other." 26

While it is clear that pre- 1868 judges were well aware of the danger that the officials responsible for counting ballots could err, by mistake or otherwise, ${ }^{27}$ we have found little suggesting that the courts of that era thought that the establishment of specific standards or uniform rules was necessary or even desirable in order to prevent such error. As far as any court might go was to ban the use by elections officials of "extrinsic evidence," by which was meant the consideration of other information besides that evident on the face of the ballots, interpreted in light of "such matters of public notoriety, as that certain well-known abbreviations are generally used to designate particular names, and the like."28 In disputed elections that

26 Id. at 307. (opinion of Campbell, J.) (requiring elections officials to disallow ballots giving the candidate's initials rather than his given names in full on the authority of Tisdale). See also id. at 310 (opinion of Christiancy, J.) (concurring on the authority of Tisdale while questioning the rule "on principle"); id. at 317 (Cooley, C.J., dissenting in part) (regretting the court's adherence to Tisdale "notwithstanding the majority are of opinion that it is unsound in principle").

27 See People ex rel. Hodgkinson $v$. Stevens, 5 Hill. 616, 626 (N.Y. Sup.Ct. 1843) (opinion of Nelson, C.J.) ("it is the duty of courts to restrain the doings of canvassers of elections strictly within the limits of the authority under which they act").

28 People v. Cook, 4 N.Y. 67, 81 came before the courts, there was disagreement over the extent to which extrinsic evidence was admissible. ${ }^{29}$ There, too, however, we have found little indication that any court believed it necessary to establish affirmative and specific guidelines to govern a jury's judgment as to voter intention.

The controlling goal, virtually every reported case agreed, was to determine correctly "the simple fact of the intention of the voters who cast their votes,"30, and as a general matter a voter's failure to follow with precision statutory or customary rules about the form of his ballots was not permitted to defeat that intention where it could be discerned. ${ }^{31}$ At the polls' closing, as one court put it

[t]he choice of the voters has become a perfect fixed fact. To make proof of that fact is all that remains to be done. Counting the votes and making the returns are not part of the election, but the mere steps of the agents of those who have voted, to make known the result. Now, it must be evident

${ }^{29}$ Compare Ely, 4 Wis. at 449-50 (facts "connected with the election" admissible "for the purpose of aiding the jury in determining who was intended to be voted for") with People ex rel. Lake, 3 Mich. 233, 235 (1854) (such evidence properly excluded).

${ }^{30}$ Matteson, 7 Peck at 169

31 See, e.g., id. ("When we are satisfied on that point [sc. the voter's intent], we are bound to give effect to such intention.”); Saxton, 22 N.Y. at 311 (voter's intent to vote for candidate by writing in his name to be effectuated despite failure to strike out name of other candidate on printed ballot); State ex rel Philips v. Goldthwaite, 16 Wis. 146 (1862). 
that it is quite immaterial to the electors and the elected, whose rights are involved in the transaction, in what way the choice of the people is discovered, if the means used suffice to carry that choice into effect. . . . Truth, if recognized, is not to be rejected because it comes through an imperfect channel. ${ }^{32}$

Indeed, the most respected constitutionalist of the time, Thomas Cooley, addressed this issue only months before the ratification of the Fourteenth Amendment was proclaimed. "The true rule upon this subject" is that "where the intent of the voter as expressed by his ballot, when considered in the light of such surrounding circumstances, is not doubtful, the ballot should be counted and allowed for the person intended." ${ }^{33}$ In the case before him, the Michigan Supreme Court divided over whether canvassing officials could accept ballots that gave the initials rather than the full given name(s) of a candidate, with a majority believing itself bound by authority to require the rejection of such ballots. As Chief Justice Cooley noted, however, the court left unquestioned as a general matter the power of local elections officials to count ballots where "the error of the voter is not so great, when the facts surrounding the election are considered, as to leave his intent in no real doubt." Cooley's views were no aberration. In the light of this fact, the Court had no basis whatever -- if the original, "time-dated" meaning of the Fourteenth Amendment is to govern -- for condemning as unconstitutional the Florida Supreme Court's adoption a

32 Day, 1 Or. at 128.

33 People ex rel. Williams v. Cicott, 16 Mich. at 319-20 (1868). practice that was traditional at the time the amendment became part of the Constitution. $^{34}$

Perhaps there is some other way to read the 19th century cases than the one we have presented; possibly there are other cases or sources that could lead someone to a different conclusion than that expressed by Chief Justice Cooley. Justice Scalia, however, did not make such an argument. In joining the per curiam opinion he simply ignored the very materials, the very question, that he has repeatedly defined as determinative for his own views on constitutional issues.

34 Two additional issues merit brief attention. (1) Although most of the cases we have found do not deal with multi-district elections of the sort before the Court today, those that do give no indication that the courts deciding them perceived the difference to be significant with respect to dealing with ambiguous ballots. See, e.g., People ex rel. Hodgkinson, 5 Hill 616 (N.Y. Sup.Ct. 1843); People ex rel. Lake, 3 Mich. 233 (1854). (2) We have been able to discover no case dealing with a presidential election. But see Ex parte Heath, 3 Hill 42 (N.Y. Sup.Ct. 1842) (stating in dicta that the principle of election law being applied "is the same, whether considered in reference to elections in municipal corporations, to county, district or state elections, or even a federal election for president"). But there obviously is nothing whatever in the text of the equal protection clause or, for that matter, our precedents, that justifies treating a state's duty to afford voters equal protection as any different when the election is for presidential electors than when it is for any other officials. The distinction that the Supreme Court has drawn in the one person/one vote cases between congressional and state-legislative districting rests on the fact that congressional districting is controlled not by the equal protection clause but by Article I. See White v. Weiser, 412 U.S. 783, 792-93 (1973). 
Judge Posner who disapproved the Equal Protection analysis tendered in the per curiam opinion has advanced a pragmatic justification for the decision by Justice Scalia and the other two concurring Justices to join the per curiam opinion despite its transparent weakness and despite its inconsistency with the majority's decision to stop the recount altogether. ${ }^{35}$ But in his view, the concurring Justices "had no real choice:"

Had they not joined the equal protection ground, the outcome of the case would have been no different - a reversal terminating the recount - but there would have been a majority to reject both possible grounds for the reversal, the equal protection ground (which by hypothesis the three concurring Justices plus Stevens and Ginsburg would have voted against) and the Article II ground (which all but the three concurring Justices would have refused - in fact did refuse to join). What a field day the critics of Bush v. Gore would then have had! $!^{36}$

In short, and on the assumption (which Posner does not examine) that the concurring Justices did not actually think the Equal Protection argument convincing, they nonetheless were justified in joining the per curiam opinion in order to reduce the Court's (which is to say their own) vulnerability to criticism.

35 Id. at 128. See also id. at 152 ("If the vice of the Florida supreme court's decision ... was the standardless character of the recount that it ordered, the logical remedy was to direct that court to adopt standards [or] dismiss the suit.").

$$
36 \text { Id. at } 168 .
$$

This argument - that a justice properly may endorse a conclusion that he deems contrary to law in order to avoid (or reduce) unfavorable commentary on his "brethren"- may be sensible for someone like Chief Judge Posner who takes what he calls "a pragmatic approach to adjudication," although it is important to note that what Posner is commending as "a bit of Realpolitik" is a deliberate refusal to obey the law or to be candid. ${ }^{37}$

For us, concern for the Court's reputation as a court of law pointed in the contrary direction of a refusal to hear the case. By deciding it on the merits, the Court passed up an extraordinary opportunity to instruct the American people on the Court's limited role in the constitutional scheme and the related responsibility of citizens to resolve such issues by democratic means. ${ }^{38}$ Such a decision would have created "a field day" for members of the profession seeking to persuade the people that the Court is indeed an institution of law and not merely, as many must always suspect, a mechanism for indulging the preferences of nine powerful individuals.

37

POSNER, BREAKING THE

DEADLOCK 169. The quotations are from a sarcastic criticism of Justice Breyer for not engaging in such Realpolitik.

${ }^{38}$ It would have been just the right occasion to quote James Bradley Thayer's very wise advice on the need to remind the people "of the great range of possible mischief that our system leaves open, and must leave open," because $[\mathrm{u}]$ nder no system can the power of courts go far to save a people from ruin." The Origin and Scope of the American Doctrine of Constitutional Law, 7 HARV. L. REV. 129, 156 (1893). 
Justice Scalia, we are pleased to affirm is not a Posnerian pragmatist, ${ }^{39}$ nor one prone to govern his actions by considerations of public relations. Consistency in the application of an appropriate constitutional methodology may be of little importance to Posner, but it is crucial to Justice Scalia's own conception of the proper judicial role. The very purpose of his "interpretive philosophy" lies "in the rejection of usurpatious new" principles of constitutional law. "My fidelity to the methodology should be judged ... by cases discovering a novel constitutional right. ${ }^{, 40}$ That is, of course, precisely what the per curiam opinion in Bush v. Gore did -"discover a novel constitutional right" to create a "usurpatious new" principle. The fact that there may have been a different argument for reaching the same result in that particular case that was perhaps less vulnerable does not explain how a Justice committed to consistency as a primary judicial virtue could join in announcing such a novel and therefore illegitimate right. As Justice Scalia wrote in United States v. Virginia:

Besides its centrality to the rule of law in general, consistency has a

39 See, e.g., Richard A. Posner, Past-Dependency, Pragmatism, and Critique of History in Adjudication and Legal Scholarship, 67 U. CHI. L. REV. 573, 595-96 (2000): "The originalists of the present day, such as Justice Scalia, are reacting to the exercise of free-wheeling judicial discretion by the courts during the era of Earl Warren and, to only a slightly lesser extent, of his successor, Warren Burger. The originalists want to minimize judicial discretion and they have devised a kind of algorithmic mechanism for doing so."

40 Scalia, Response, in A MATTER OF INTERPRETATION 139. special role to play in judge-made law - both judge-pronounced common law and judgepronounced determinations of the application of statutory and constitutional provisions. Legislatures are subject to democratic checks upon their lawmaking. Judges less so, and federal judges not at all. The only checks on the arbitrariness of federal judges are the insistence upon consistency and the application of the teachings of the mother of consistency, logic. ${ }^{41}$

The Supreme Court of the United States does not sit to announce "unique" dispositions. Its principal function is to establish precedent--that is, to set forth principles of law that every court in America must follow. As we said only this Term, we expect both ourselves and lower courts to adhere to the "rationale upon which the Court based the results of its earlier decisions." ... That is the principal reason we publish our opinions. $^{42}$

\section{The ConCurring OPINION: THE Plain Language of Article II}

Not only did Justice Scalia join in the per curiam opinion refusing to consider the "time-dated" meaning of the Equal Protection Clause, but he also signed a concurring opinion of Chief

41 Scalia, Assorted Canards, 40

CASE W. Res. L. REV. at 588.

42518 U.S. 515, 596 (1996) (Scalia, J., dissenting), quoting Seminole Tribe of Fla. v. Florida, 517 U.S. 44, 66-67 (1996) (emphasis added). 
Justice Rehnquist that seems to us (notwithstanding Judge Posner's defense of it) to flout the plain meaning of Article II of the Constitution. That opinion proposed an alternative basis for the Court's decision. Article II, $\S 1$, cl. 2, of the Constitution provides that "[e]ach State shall appoint, in such Manner as the Legislature thereof may direct," its presidential electors. The concurrence reasoned that the Florida court's order of a recount of the undervote was so substantial a "depart[ure] from the legislative scheme" that it unconstitutionally encroached on Article II's delegation of power to the Florida legislature to direct the manner in which presidential electors are to be appointed. ${ }^{43}$ The concurring Justices therefore concluded that "[f]or these reasons, in addition to those given in the per curiam," the Florida court order ought to be reversed. ${ }^{44}$

Indeed, it could scarcely be more plain that the authors and ratifiers of Article Two regarded the selection of the state's presidential electors to be in the first instance a task for the Florida legislature, but how the legislators chose to do this was their business. They might, as far as the federal Constitution is concerned, have chosen to count no votes but their own as the elected representatives of the people of Florida and have chosen electors according to their own preferences. Of course, no state legislature has chosen this course for many years, presumably because the people of the state would promptly throw all the rascals out. Like all other states,

43531 U.S. at 120 (Rehnquist, C.J., concurring).

44 Id. at 122 (Rehnquist, C.J., concurring). therefore, Florida has chosen to engage the services of citizen voters, local governments, and the courts of the state for specific and varying roles in the selection of presidential electors. Each of these bodies and institutions has a limited role and in the end the designation of presidential electors remains, as the Constitution provides, with the legislature.

After ratification of the Fifteenth and Nineteenth Amendments, Florida could not discriminate among voters on the basis of their race or gender, but these are the only textual provisions in the Constitution of the United States bearing on the states' authority to choose their electors in a manner agreeable to its own elected representatives. If, as Judge Posner and other defenders of the majority contend, the decision of the Supreme Court of Florida was lawless, the legislature remained free, insofar as federal law is concerned, to disregard that decision and certify presidential electors according to its own best judgment. If the legislature was inhibited in following that course, the inhibitions came from the text of the Florida constitution and the fear of an adverse response of the people to a decision that they might have deemed illegitimate.

Article II of the Constitution of the United States provides that the vote of each state's electors is reported to the President of the United States Senate, and the votes are tabulated in a joint session of Congress. The final authority for resolving a contested presidential election resides in the elected members of the United States House of Representatives.

Just as it is plain that the primary responsibility rests with the Florida legislature, it is equally plain that the architects of the Constitution went to some trouble to avoid any invitation to the 
life-tenured Justices to participate in the selection of the President. The connecting thread in the constitutional system the Founders devised for choosing the President is that the bodies constitutionally entrusted with responsibility are, in each instance, accountable to the people and can be dismissed from office if the commit the $\sin$ of selfdealing. If it were a good idea to involve the life-tenured Justices in picking the President who picks them, James Madison, Alexander Hamilton and their colleagues would have been smart enough to arrange that.

There was, however, as we have noted, a compelling reason not to give Justices a role in Presidential elections. Of all the public officials in the United States other than the candidates themselves, those having the greatest personal stake in the outcome of a presidential election are the Justices of the Supreme Court. The point is so obvious that it needed no discussion at Philadelphia, or in the Federalist Papers, or elsewhere when the Constitution was being debated. Nor, it seemed to us, should it have been necessary to call this to the attention of a professed textualist such as Justice Scalia. ${ }^{45}$ Yet the point has

45 When the argument was made to the Court a few years ago that it could review the procedures by which the Senate tries judges who have been impeached, the Court dismissed the argument as "counterintuitive" because it would "place final reviewing authority with respect to impeachments in the hands of the same body that the impeachment process is meant to regulate." Bush v. Gore reached a conclusion equally at odds with "with the Framers' insistence that our system be one of checks and balances" on the judiciary as well as on the political branches. Nixon v. United States, 506 U.S. 224, 234-35 (1993). received very little attention in the literature about the case.

\section{THE STAY ORDER}

Justice Scalia made a brief attempt to defend the Court's December 9 order temporarily staying the Florida recount three days before it decided that the count should be permanently stayed. He wrote that the stay was proper because "[c]ount first, and rule upon legality afterwards, is not a recipe for producing election results that have the public acceptance democratic stability requires." ${ }^{46}$ This sentence is both puzzling (counting the votes first and ruling upon the legal issues afterwards is the ordinary course of election-related litigation) and unintentionally revealing. It is not in fact the task of the courts or the litigation process to "produce" election results or, for that matter, democratic stability in any direct sense. The stability of democratic government depends primarily on democratic politics that assure citizens of the right and power to choose those making important public decisions and to discard self-aggrandizing public officers.

Of the decisions made by the Court in Bush v. Gore, the stay order is the least defensible. Even if there were substance to either of the constitutional arguments advanced in the per curiam and in the concurring opinions, there is no justification for the stay order except the realpolitik argument advanced by Judge Posner. Self-serving realpolitik is the only possible explanation of the Scalia utterance with regard to the stay. If indeed, the Florida court must supply detailed standards, it was for it to decide whether there was time to do so. If

46 Bush v. Gore, 531 U.S. 1046, 1046 (2000) (Scalia, J., concurring). 
indeed, the issue is for the legislature under Article II, neither is that a reason for those with life tenure to stop the count.

\section{WHAT REMAINS OF SELF-GOVERNMENT?}

The fundamental point we wish to make regarding Justice Scalia's behavior in Bush v. Gore has little to do with his (or any other Justice's) personal failings or lapses in consistency. Our reason for directing attention to his votes is that he was the Justice most likely to take seriously the duty to obey legal texts in an important case involving the power and self-interest of the Justices themselves, and thereby most likely to respect the institutions of self-government. His disregard of that duty reveals the Court as an arrogant band of men and women having scant respect for representative government.

In the situation before the Court, the Constitution on its face provided for a political means of resolving the Florida vote controversy and, thus, the presidential election. If the recount had continued under the Florida court's December 8 order, the ballots would have been recounted as ballots have traditionally been counted in this country, by hand and on a local basis by officials having no direct personal stake in the outcome, and under a standard that is both traditional and the one ordained by the Florida legislature. It was that legislature, after all, and not the state supreme court, which created the rule that " $[\mathrm{n}] \mathrm{o}$ vote shall be declared invalid or void if there is a clear indication of the intent of the voter as determined by the canvassing board." 47

47 Fla. St. $\S 101.5614$.
Furthermore, accepting for the sake of argument the concurrence's insistence that Article II vests the state legislature with the sole and curiously undelegable power to determine how a state's electors are to be appointed, there is - as noted -no reason to doubt that the Florida legislature retained the power to select a slate of electors whatever the result of a recount - and indeed the legislature was on the verge of doing so when the Supreme Court relieved it of further responsibility.

In any event, and regardless of what came out of Florida, under Article II and the Twelfth Amendment, the joint session of both houses of Congress in the first instance, and the House of Representatives in the event the electoral vote count in the joint session did not produce an electoral college victor, had the textually committed power to determine who was elected President. ${ }^{48}$ The Court appears to have found it intolerable to permit the election controversy to be resolved by these who were elected to resolve it and who would have to risk the displeasure of voters if they resolved it wrong, despite the fact that it was overwhelmingly likely that the result would be to place Governor Bush in the White House. (This latter point is overlooked by those who focus narrowly on the apparently partisan - five Republicans outvote four Democrats nature of the decision.) The danger or unseemliness or undesirability of a resolution by persons accountable to the people was so pressing in their minds that

48 See Posner, BREAKING THE DEADLOCK 184-85 (constitutional issues arising from the joint session's decisions on counting the electoral votes probably would have been political questions unreviewable by the courts). 
resolution by the Court appeared preferable even though it produced the bizarre result that the Court itself determined which candidate would be vested with the power to appoint its members.

There is nothing new in the observation that members of the Court, other members of the judiciary, and prominent members of the profession often display in their decisions an alienated disdain for the processes of American democratic politics. ${ }^{49}$ What is significant about Justice Scalia's behavior in Bush v. Gore is that it shows how deep this resistance to decision by political means has become. Even an elaborate, publicly professed "interpretive philosophy" takes a back seat, it seems, to the impulse to displace the messiness of politics with the ostensible reasonability and order of judicial decision-making when it comes to deciding a case of elevated personal interest to the Justices.

As in many other situations where (in our judgment, at any rate) the Supreme Court has usurped power properly lodged in the political branches or in the states, it appears that the Court got away with Bush v. Gore. $^{50}$ There is, at present, no substantial body of opinion, either among

49 The point has been made by each of us, among others. See CARrINGTON, SteWARds of Democracy (1999); POWELl, THE MORAL TRADITION OF AMERICAN CONSTITUTIONALISM (1993).

50 See Herbert M. Kritzer, The Impact of Bush v. Gore on Public Perceptions and Knowledge of the Supreme Court, 85 JUDICATURE 33, 37 (2001) (although "Republicans became more supportive and Democrats ... less," "the net effect on the public's evaluation [of the Court] is essentially nil"). the public generally or in the legal profession or the academy (where most constitutional law scholars support an expansive role for the Court) that objects in a systematic fashion to the Court's enthusiasm for self-aggrandizing countermajoritarianism, and for understandable reasons. While individual decisions of the Court anger significant numbers of people with some frequency, as an overall matter the Court's decisions keep it reasonably close to the political center of gravity of an economically privileged ruling class. The legal profession in America is very large and very powerful and its members seem to perceive that their status and power is somehow linked to that of the Justices. The long-standing and deep-seated reverence most Americans feel for the Republic's basic system of government will probably therefore continue to shelter the Court from the consequences one might otherwise expect when a governmental institution in a democracy becomes selfcentered. For most Americans, the concerns that we raise about decisional integrity and respect for representative government seem too abstract, too bloodless to raise any sustained passion.

Indeed, there appears to us to be a false sense that it is uncivil and unprofessional as well as unpatriotic to call attention to self-aggrandizement by the Justices. Perhaps because they do their work in a building designed to resemble a pagan temple, many who must know better seem reluctant to call attention to the Court's self-dealing. We sense among lawyers a special unwillingness to recognize the reality of what the Court did.

Perhaps we are less than civil in calling attention to that reality. However, the costs to American society of permitting the Court to behave as it did in 
Bush v. Gore seem real to us. There are occasions when incivility is a public duty.

The Court's membership is drawn from a narrow segment of American society, and its perception of public policy bears the stamp of that narrow class's interests and concerns. ${ }^{51}$ Moreover, widespread acceptance of judicial politics "erod[es] the habits and temperament of representative democracy." ${ }^{52}$ The honor, gratification, and

51 To document this assertion is a task for another day, but consider as an example the Court's abortion jurisprudence. Roughly speaking, what the Court has done is create a regime in which (a) anyone with access to upper middle-class finances can obtain an abortion, although (b) in any individual state a significant number of obstacles to doing so (which disproportionately affect poorer women) can be imposed, and (c) government need not fund abortions so that the well to do need not subsidize the poor on this matter. As many other commentators have observed, this constellation of outcomes, however the Justices consciously arrived at it, perfectly mirrors the selfish interests of well to do Americans. responsibility of those holding elective office are diminished. And so, also, are the honor, gratification, and responsibility associated with the performance of one's duty as a citizen to vote on important matters. Even before Bush v. Gore, the Court had made itself the central issue in six consecutive presidential elections, limiting the ability of those seeking popular support from gaining public attention on public issues worthy of discussion. The decision in that case thus accelerates the degradation of all public offices outside the life-tenured federal judiciary and enhances the sense of citizens that they are not the masters of the Republic.

We do not suggest that elected representatives of the people make wise decisions. Often they do not. The great advantage of having disputes resolved by them and not by the Court is that the people share in the responsibility for decisions made by those they choose and they can throw the rascals out when they do the wrong thing. Even if those elites serving with life tenure have better judgment than the people or their representatives, -- and we do not concede that they do -- they cannot provide either of those very great advantages that are the source of the stabilizing effect of democratic government.

We note that a similar degradation of democratic traditions is occurring in other countries in which high courts are seeking to emulate the Supreme Court of the United States. ${ }^{53}$ The

\footnotetext{
${ }^{52}$ F. L. MORTON \& RAINER KNOPFF, The CHARTER ReVOlution AND THE COURT PARTY 149 (2000).

53 See also Haig PATAPAN, JUdGING Democracy: THE NeW POLITICS OF THE High Court of Australia (Cambridge UK
} 
observations of F.L. Morton and Rainer Knopff about the expanding political role of the Canadian courts are equally applicable to this country:

The growth of courtroom rights talk undermines perhaps the fundamental prerequisite of decent liberal democratic politics: the willingness to engage those with whom one disagrees in the ongoing attempt to combine diverse interests into temporarily viable governing minorities. Liberal democracy works only when majorities rather than minorities rule, and when it is obvious to all that ruling majorities are themselves coalitions of minorities in a pluralistic society. Partisan opponents, in short, must nevertheless be seen as fellow citizens who might be future allies. Representative institutions facilitate this fundamental democratic disposition; judicial power undermines it. ${ }^{54}$

Returning constitutional law and the Court to their proper, limited roles in American democracy would not be easy. But it cannot be done at all if the Court is free to interfere with the Republic's fundamental democratic processes with the acceptance and approval of the legal

2000); Kate Malleson, The NeW JUDICIARY: THE EFFECTS OF EXPANSION AND ACTIVISM (Ashgate 1999); U. C. JAIN \& JEEVAN NAIR, JUDICIARY IN INDIA 140-259 (Jaipur 2000). Judging from these works, it appears that the Brennan vision of the antidemocratic role of the judiciary is infectious among English-speaking judges.

129. profession and the academy, and if individual Justices are not held accountable in public discussion when they disregard their own expressed principles out of a disdain for democratic politics and an ambition to protect and enhance their own individual powers.

\section{CONCLUSION}

In the United States, the political legitimacy of courts exercising judicial review is settled and we do not mean to suggest that this feature of our system should or could be abolished, although we do believe that current practice goes beyond what can be justified. American courts ought exercise their powers of judicial review only in the democratic tradition in which majoritarian political decision-making is the norm. Even when they displace such decisions, those with life tenure have no commission to do so other than on the basis of constitutional norms that themselves were the product of majoritarian political processes.

"It is quite impossible for the courts, creatures and agents of the people of the United States," Justice Scalia affirmed, "to impose upon those people of the United States norms that those people themselves (through their democratic institutions) have not accepted." Unfortunately, such impositions are by no means impossible, only antidemocratic and wrong. And especially wrong, it seems to us, when the effect is selfaggrandizing enhancement of the personal power and status of the Justices themselves.

If there be readers who are able and willing to explain why the decision in

55 Scalia, Commentary, 40 ST. LOUIS U. L.J. at 1122. 
Bush v. Gore was not manifest selfaggrandizement, or who are able and willing to explain to us how that decision can be reconciled with a republican form of government, we would be grateful for their illumination. 